\section{Biotechnologists seek to bridge South Asian divide}

K. S. Jayaraman, Hyderabad

Biotechnology collaborations have been agreed between India and Pakistan, ending more than five decades of scientific impasse between the two nations.

Last week, a Pakistani delegation to the BioAsia 2004 meeting in Hyderabad signed five agreements - three with Indian biotechnology companies and two with the All India Biotech Association (AIBA). The agreements are said to be the first involving a high-technology area to have been struck between the rivals.

"I will go back to my country extremely pleased," says Anwar Nasim, chairman of Pakistan's National Commission on Biotechnology, who led the delegation.

"We intend to collaborate with Indian companies in the areas of industrial products, vaccines, diagnostic kits and transgenic crops," Nasim told Nature. Under the agreements, the AIBA will help Pakistan to establish its own biotechnology association and will provide a list of Indian technologies that are available for licensing in Pakistan.

B. S. Bajaj, a senior AIBA official, says that in the long term the partnership should benefit both nations. "Indian technology could help Pakistan to bring down the price of its drugs, which are six to seven times more costly than in India," he says. "And Indian biotechnology companies will benefit from opening up a new market in their backyard."

The agreements are general in nature, however, and "we will have to see how they progress", cautions the AIBA's Ashok Sadim Khan. Nasim agrees that "complex issues will have to be dealt with" before the agreements are implemented. But he adds: "All I can say is that we are making a start, and are confident that many avenues will open up for collaboration."

Nasim says that prospects for improved relations between Indian and Pakistani scientists are looking brighter. "Our academy has already received an invitation from the Indian National Science Academy (INSA) and we are considering it," he adds. INSA secretary S. K. Sahni told Nature that, because things move slowly at government-to-government level, the INSA had decided to offer to launch discussions with the Pakistan Academy of Sciences on such common interests as agriculture and malaria.

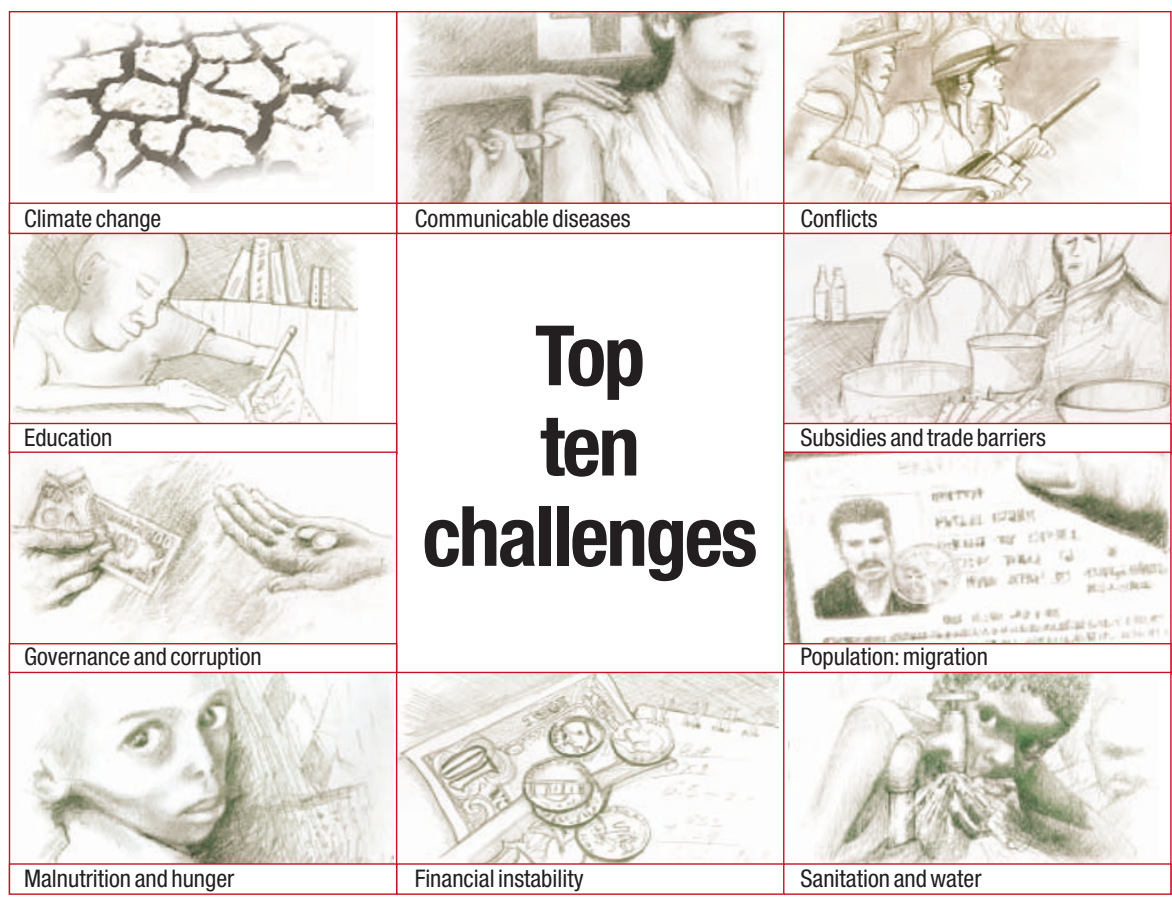

\title{
Problems of the poor set to face cost-benefit treatment
}

Jim Giles, London

Bjørn Lomborg was vilified by the green movement when he published The Skeptical Environmentalist, a 2001 book that questioned the validity of several widely held beliefs about the state of the planet. A furious activist went so far as to thrust a pie in his face, on at least one occasion. But his next big venture could see him rouse the ire of an equally passionate group: the international aid movement.

As part of Lomborg's latest scheme, nine eminent economists will gather in Copenhagen on 24-28 May to rate solutions to the developing world's ten largest problems, from financial instability to communicable diseases (see above). The panel intends to use cost-benefit analyses to evaluate between three and five rival approaches to each problem. The result, says Lomborg, will rank the most cost-effective ways of doing good.

It could also be the recipe for a major row. International charities say the scheme ignores established targets, such as those developed by the United Nations. Some economists say that Lomborg is overstating the usefulness of cost-benefit analysis - a technique that has long been used by conservative economists to support arguments against everything from clean-air rules to development aid for the poor. "To believe the problems of the world can be solved like this is absurd," says Eric Neumayer, an expert in environment and development at the London School of Economics.
The economists planning to take part in the assessment mostly reside in élite universities in Europe and the United States, and four of them are Nobel laureates. They will each assign numbers to potential solutions, of which there are around 30; the numbers will represent the size of the benefits that come with the approach, such as fewer cases of disease, minus the costs of implementing it.

Cost-benefit analyses have become more common in aid planning over the past decade, but remain controversial nevertheless. Economists have to assign values to variables in the analyses, such as human life, and the numbers they use can vary widely. Critics such as Neumayer say that for some problems, such as climate change, the variability is far too great for the results to be meaningful.

Others point out that the quantitative approach, if it were adopted by aid agencies, would inevitably push effort away from the toughest problem areas — such as war-torn southern Sudan. "There is little chance of effective use of money there," says Roger Riddell, international director of Christian Aid, a London-based charity. "But it should not be abandoned."

Lomborg acknowledges that some countries could lose out, but argues that we already prioritize aid funding and that this is simply a better way of doing it. "There's never an easy answer," he says. "But if there are places where we can do relatively little then we should consider achieving more elsewhere."

www.copenhagenconsensus.com 